\title{
Proceeding
}

9th INSHS International Christmas Sport Scientific Conference, 4-6 December 2014. International Network of Sport and Health Science. Szombathely, Hungary

\section{Swimming as a part of early childhood education in Czech Republic}

\author{
BRIGITA STLOUKALOVÁ $\square$, TOMÁŠ ROZTOČI \\ Department of P.E. and Sport, Faculty of Education, University of Hradec Králové, Czech Republic
}

\begin{abstract}
Stloukalová, B., \& Roztočil, T. (2015). Swimming as a part of early childhood education in Czech Republic. J. Hum. Sport Exerc., 9(Proc1), pp.S181-S191. There has been the swimming education a compulsory part of PE since 1970' in Czech Republic. Originally the swimming education related only to elementary schools but during the last twenty years the system of the swimming education turns to kindergartens. Today the swimming education is an obligatory part of school curriculum, not compulsory one. Swimming is a favourite movement activity in Czech Republic and in general, swimming is also considered beneficial to the physical, psychical and social development of children. This fact implies that there is a great parents' interest in the swimming education of even the youngest children. Twenty years ago Swimming Schools was founded. They specialize in providing of the swimming education for the schools and they offer place, methodic and personal matters. In years 2006 - 2012 we carried out a research in kindergartens in several regions focused on interests of kindergartens in the offer. Our goal was to find optimal conditions - material, personal and financial - for the swimming education of preschool children. Now the research has continued, it focused on the used methods and our final aim is to create an ideal concept of swimming education for kindergartens. Key words: SWIMMING EDUCATION, SWIMMING SCHOOLS, CONDITIONS FOR SWIMMING EDUCATION, CZECH REPUBLIC.
\end{abstract}

Corresponding author. University of Hradec Králové, Rokitanského 62, 50003 Hradec Králové, República Checa E-mail: brigita.stloukalova@uhk.cz 9th INSHS International Christmas Sport Scientific Conference, 4-6 December 2014. International Network of Sport and Health Science. Szombathely, Hungary.

JOURNAL OF HUMAN SPORT \& EXERCISE ISSN 1988-5202

(c) Faculty of Education. University of Alicante doi:10.14198/jhse.2015.10.Proc1.04 


\section{INTRODUCTION}

Since 1970s a unique and elaborated system of organized swimming education was arising in Czechoslovakia. Swimming education was realized within compulsory education in the second and third grades of elementary schools. The Ministry of Education, through state budget, and the Czechoslovakian State Insurance Company were financially involved in this education (Hoch, 1983). During 1990s so called "swimming schools" were founded for the swimming education. The swimming schools became educational institutions under the patronage of the council of schools (Pírková, 2008; Stloukalová > Roztočil, 2013). This meant a step forward because the swimming education was not anymore provided by swimming coaches but by teachers. Another turn in development was in 2005 when the new school law came into force. Although this law meant a step forward in many respects, it was the other way round concerning the swimming education. The swimming education was no more a part of the school curriculum, which resulted in reduction of schools that had provided this education for pupils (Pírková, 2008; Stloukalová > Roztočil, 2013).

So much for the history of compulsory swimming education at elementary schools which influenced the swimming education of preschool children in Czechoslovakia as well. (Stloukalová > Roztočil, 2013) In 1970s and 1980s many specialists such as paediatricians, pedagogues, sports experts, hygienists and others polemized about beneficial and harmful effects of swimming on children. Major arguments concerned so called baby swimming, i.e. swimming for children to the age of three. Specialists, supporting baby swimming, argued for the contribution to the children's health; the opponents were emphasizing premature acceleration of children's psychomotor development and were referring to hygienic issues. Arguments between both groups and poor technical base hobbled the development of baby swimming (Hoch, 1983). Moreover, swimming of preschool children was not in a good condition as well because of lack of suitable pools of adequate size (depth, length) and water temperature. The education was temporarily realized in sauna and rehabilitation pools (Stloukalová > Roztočil, 2013). The situation completely changed at the of 1990s, mainly because more suitable pools were constructed in hotel complexes, rehabilitation centres, fitness centres, pensions and next to detached houses. Suddenly, there was no problem to build a small pool without raised demands on funding. Baby swimming and, in relation to it, swimming education of preschool children became a profitable business. Various methodical schools of baby swimming started to emerge, some of them in connection to foreign schools; some of them founded nets of baby swimming clubs similar to business corporations. Among the Czech most well known and widespread schools belong Baby club Juklík, Kenny Baby and Plaváček (Stloukalová > Roztočil, 2013). Their success would not be possible without immense public interest and parents that are willing to pay considerable amounts of money for swimming education of their children.

Great interest of parents in swimming of infants, toddlers and preschool children on one side along with availability of suitable background and the licence for a preschool swimming education instructor on the other side have started boom of baby swimming in the Czech Republic. The first stage of our research was to find out spatial, material, personal, time and financial conditions of swimming education designed for kindergartens. The aim is to find out what types of swimming education there are and whether these are effective. For example, how the pool availability, its staffing, material facilities and financial demands influence the attendance of the swimming education.

The next stage of the research is focused on the evaluation of swimming education by kindergarten teachers and parents. Finally, the emphasis is put on the analysis of used methodology and didactics of the education in swimming schools and the evaluation of their effectiveness. 


\section{MATERIAL AND METHODS}

\section{Participants}

Table 1 characterizes addressed counties, number of inhabitants and kindergartens. Returnability of questionnaires is stated in the last column.

\begin{tabular}{|c|c|c|c|c|}
\hline county & $\begin{array}{l}\text { number of } \\
\text { inhabitans }\end{array}$ & $\begin{array}{l}\text { number of ki } \\
\text { addressed/ }\end{array}$ & & $\begin{array}{c}\text { returnability } \\
(\%)\end{array}$ \\
\hline Ústí nad Orlicí & 139 & 95 & 90 & 95 \\
\hline Žd’ár nad Sázavou & 119 & 75 & 72 & 96 \\
\hline Olomouc & 232 & 95 & 43 & 45 \\
\hline Svitavy & 105 & 82 & 76 & 93 \\
\hline Chrudim & 104 & 50 & 47 & 94 \\
\hline Česká Lípa & 103 & 50 & 20 & 40 \\
\hline Jablonec nad Nisou & 90 & 37 & 31 & 84 \\
\hline Semily & 74 & 44 & 17 & 39 \\
\hline Náchod & 112 & 61 & 44 & 72 \\
\hline $\begin{array}{l}\text { Rychnov nad } \\
\text { Kněžnou }\end{array}$ & 79 & 49 & 30 & 61 \\
\hline Brno - město & 379 & 113 & 92 & 81 \\
\hline Praha 5 & 79 & 40 & 34 & 85 \\
\hline Praha 4 & 128 & 42 & 33 & 79 \\
\hline Pardubice & 168 & 53 & 34 & 64 \\
\hline Liberec & 171 & 88 & 40 & 45 \\
\hline Hradec Králové & 163 & 65 & 45 & 69 \\
\hline Nymburk & 94 & 47 & 43 & 91 \\
\hline summary & 2339 & 1086 & 791 & 73 \\
\hline \multicolumn{5}{|c|}{$\begin{array}{l}\text { Legend: } \\
\text { agricultural county } \\
\text { metropolitan county } \\
\text { industrial county }\end{array}$} \\
\hline
\end{tabular}

Figure 1 shows the size of kindergartens according to the number of children. In Prague 4 and Prague 5 there are mostly kindergartens with more than 100 children. On the contrary, Rychnov nad Kněžnou does not have any kindergarten with the number of children over 50 , Semily over 100 . We can see differences between Prague and country counties. 


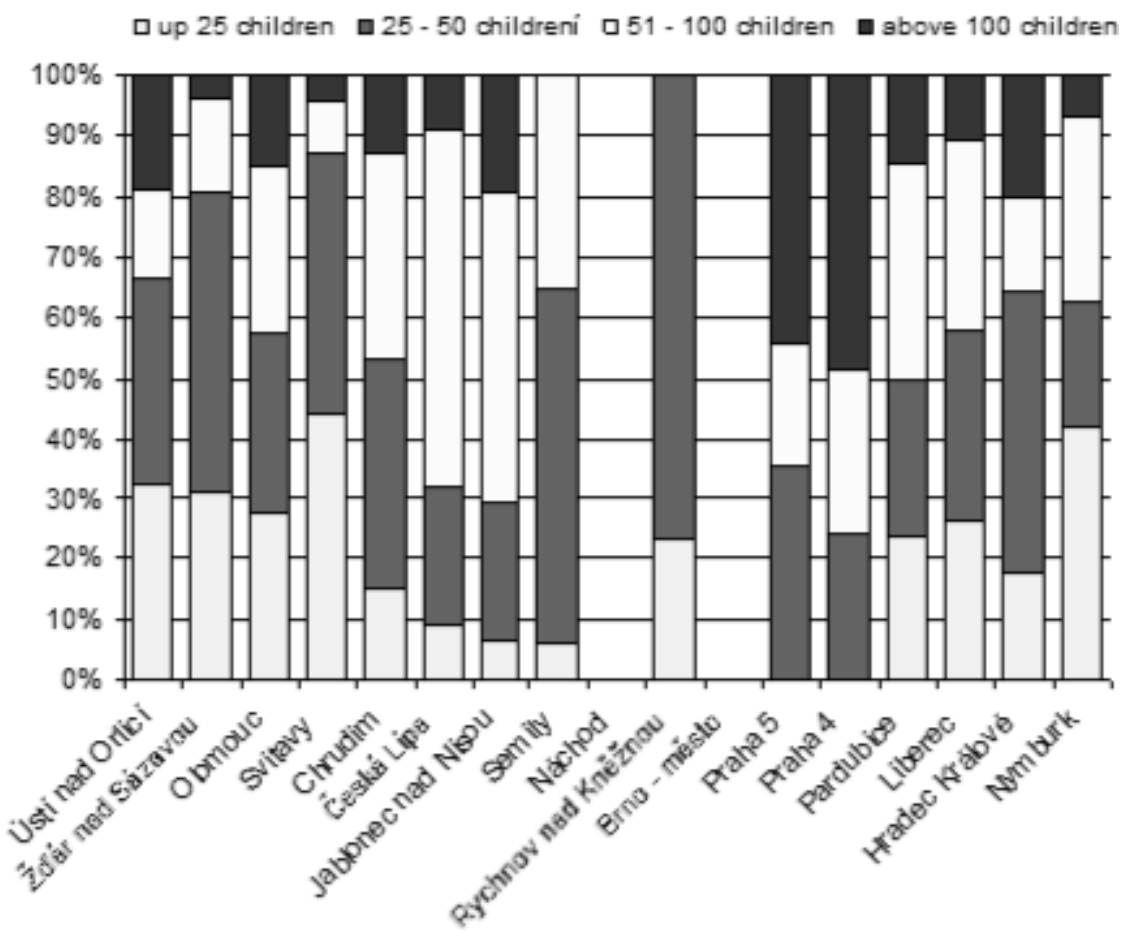

Figure 1. Size of kindergartens according to the number of children (source: authors)

\section{Measures}

A self-made questionnaire containing ten questions (either of closed and open type) was used for the purposes of this research (Gavora, 1996; Thomas > Nelson, 1996). The questions are focused on three areas:

1. Localizing and identifying individual kindergartens.

2. Finding conditions for swimming education - number of pools, their characteristics and availability. In relation to this, we also concentrated on finding reasons for non attending swimming education by kindergartens.

3. Focusing on organization and provision of swimming education - its structure and personal and financial demands.

\section{Procedures}

The questions were given to the management of kindergartens in 17 counties in the Czech Republic, which represents 2.3 mil. inhabitants, i.e. $22 \%$ of the population of the Czech Republic (Figure 2). 


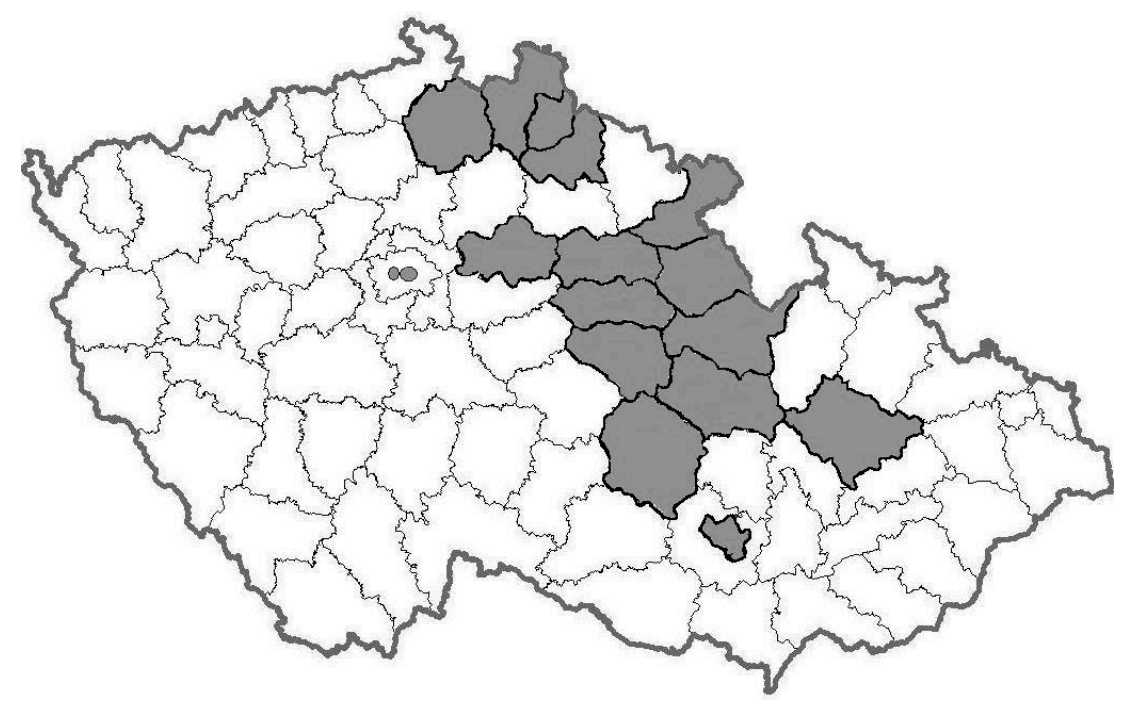

Figure 2. Map of researched counties (processed by Czech Statistical Office)

\section{RESULTS}

In the area of finding conditions we were examining the driving distance between the kindergarten and the closest pool and number of pools and their size. Figure 3 shows presumable differences among counties. Kindergartens in metropolitan counties can easily find a pool for education on-site. On the contrary, in agricultural counties 10-30 km distance prevails. An exception is, again county Rychnov nad Kněžnou (regarding its size).

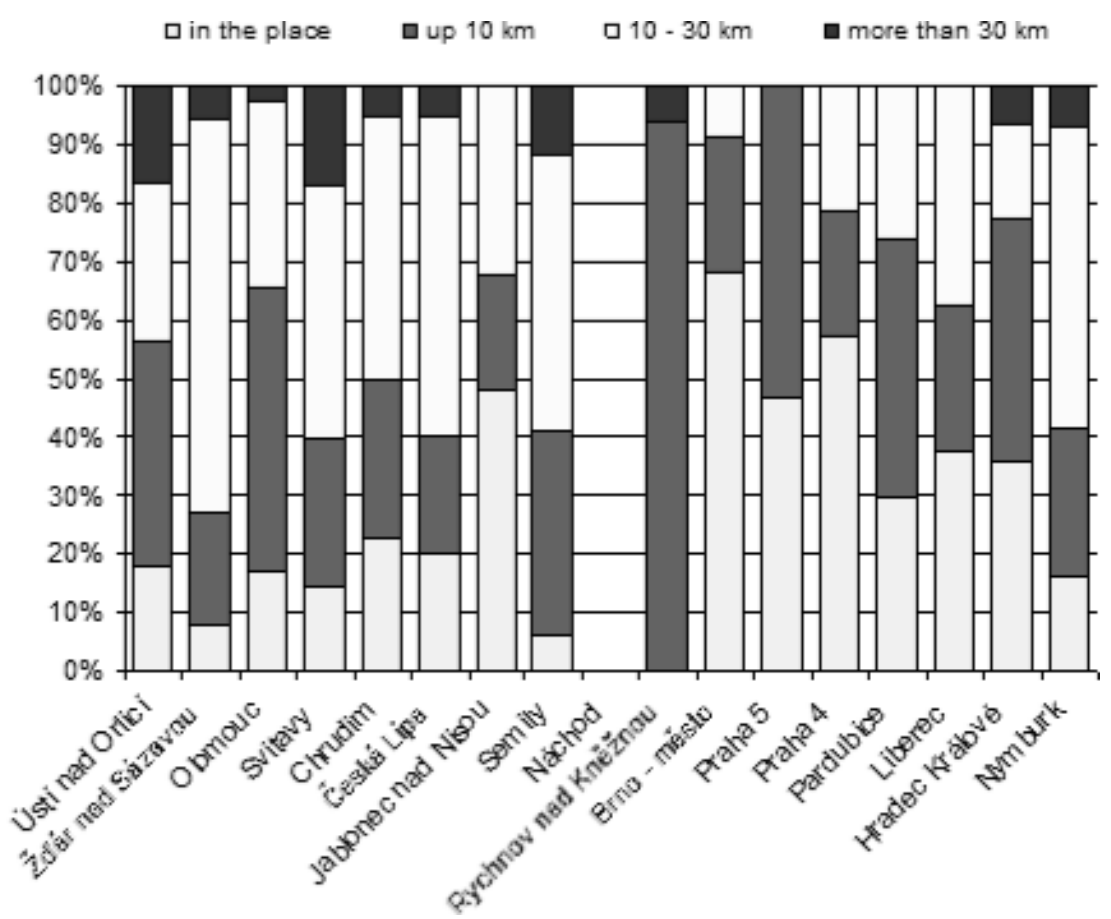

Figure 3. Driving distance between kindergartens and pools (source: authors) 
The total number of kindergartens, attending swimming education, is 590 (75\%); 201 kindergartens do not attend the education. The attendance of swimming education in individual counties is shown in Figure 4. The lowest attendance is recorded in Liberec. Liberec is industrial town in mountains, there are longer driving distances for small kindergartens in countryside but long winter is more important for schools. Other counties with lower attendance (about $60 \%$ ) are Rychnov nad Kněžnou and all metropolitan counties Brno and Prague 4 and 5 . Contrarily, attendance over $80 \%$ is to be found in purely rural counties where the driving distance of schools to pools is considerable, for example Semily (the smallest county), Jablonec nad Nisou (neighbour of Liberec with the same climate conditions).

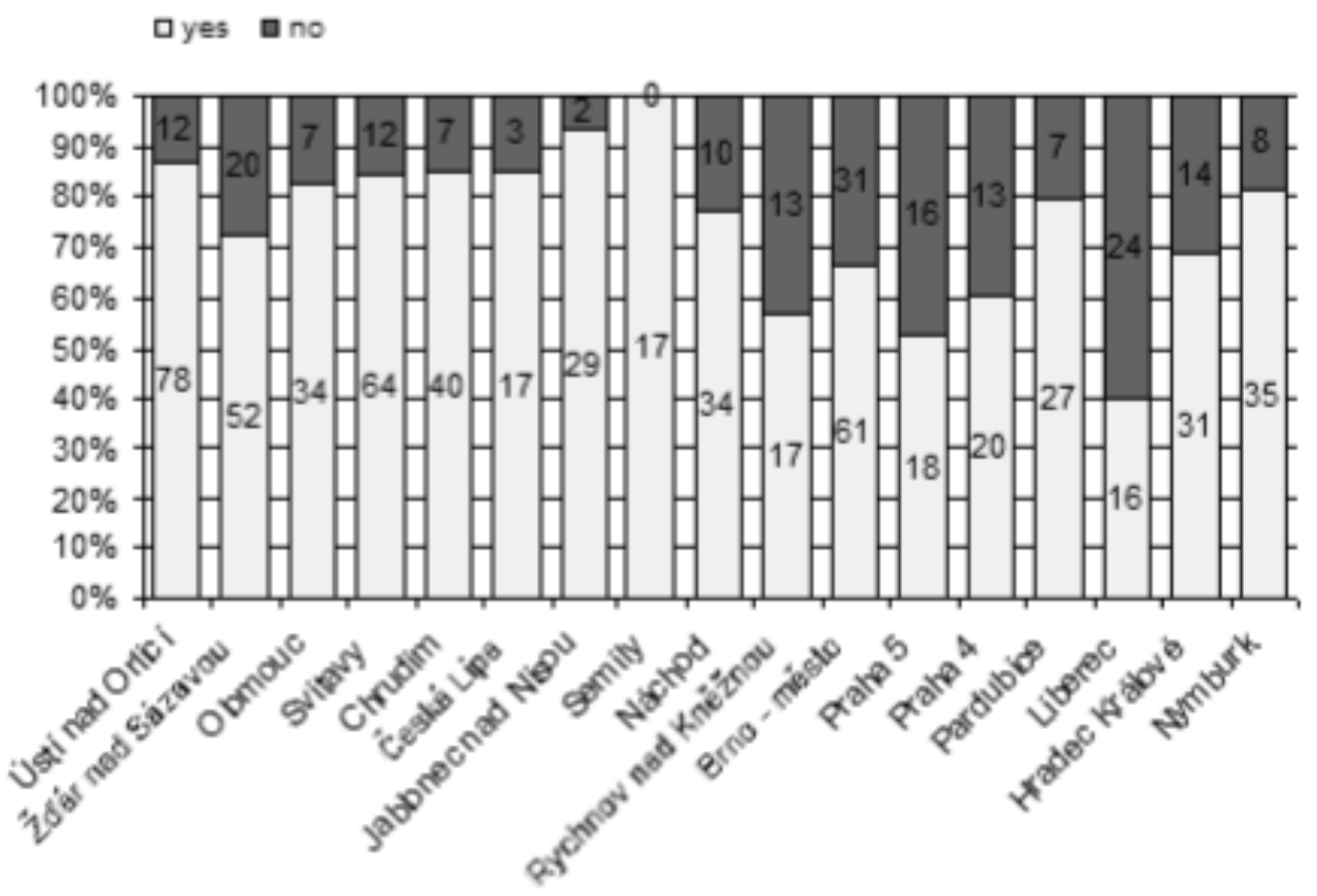

Figure 4. Kindergartens' attendance of swimming education - individual counties (source: authors)

Comparison of Figure 3 and 4 shows that longer driving distance does not negatively influence the attendance. When Figure 3 is compared to Table 1, one can see that more influential factor is the character of the county. The attendance is lower in metropolitan counties. Moreover, there hasn't been proved any dependent relation concerning size of the kindergarten.

In connection with distance between kindergarten and pool we investigated with way of transport to the swimming pool. There are used four options of transport: bus providing with swimming school or kindergarten, public transport and walking. Let us look at Figure 5 mostly transport is carried out with bus, only in Prague 4 and Hradec Králove bus is $40 \%$, this is more than $50 \%$ in other counties independently of character of county. 


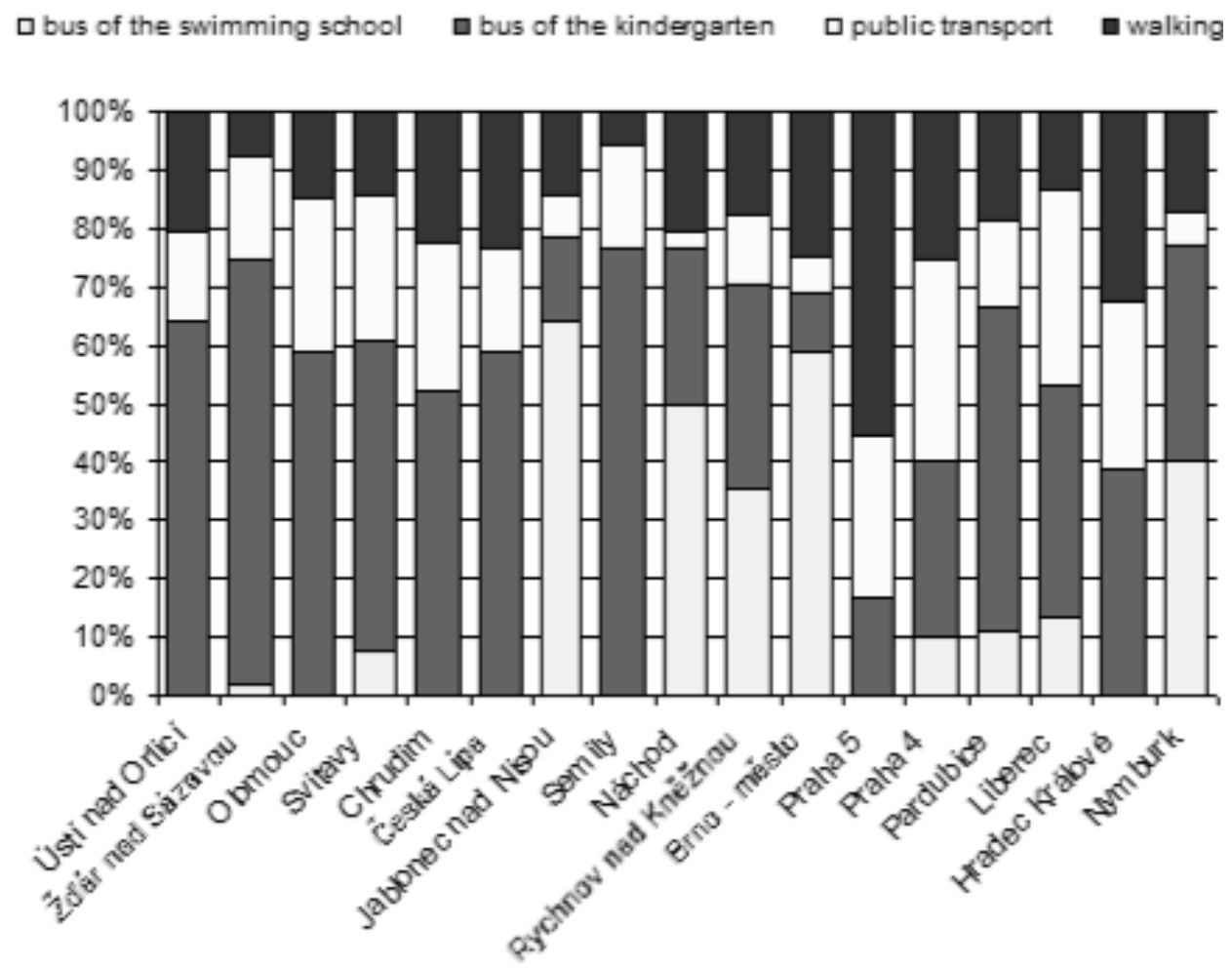

Figure 5. Ways of transport to the swimming pool (source: authors)

The number and size of the swimming pools is displayed in Table 2. Usual size of the swimming pool is length $25 \mathrm{~m}$, depth $1.5 \mathrm{~m}$. But the swimming pools of non-standard size are also built at some schools. In the whole research population there are six pools $50 \mathrm{~m}$ long (Olomouc, Brno-City, Prague 4, Pardubice, Liberec, Hradec Králové). Most pools are situated in Brno-City (six $25 \mathrm{~m}$ long pools and fifteen school pools). The worst conditions are in county Pardubice - only one $50 \mathrm{~m}$ long pool, which is not suitable for kindergarten swimming education; but there is also a special pool designed for preschool swimming education in the pool's premises. Six kindergartens in this county use the opportunity to commute to more suitable pools located in neighbouring counties (Chrudim, Hradec Králové).

Table 2. Number and size of the swimming pools (source: authors)

\begin{tabular}{cccc}
\hline \multirow{2}{*}{ county } & \multicolumn{3}{c}{ \# swimming pools } \\
\cline { 2 - 4 } & $50 \mathrm{~m}$ & $25 \mathrm{~m}$ & other \\
\hline Ústí nad Orlicí & 0 & 3 & 1 \\
Žd'ár nad Sázavou & 0 & 2 & 1 \\
Olomouc & 1 & 1 & 3 \\
Svitavy & 0 & 3 & 1 \\
Chrudim & 0 & 3 & 0 \\
Česká Lípa & 0 & 2 & 1 \\
Jablonec nad Nisou & 0 & 1 & 1
\end{tabular}




\begin{tabular}{cccc} 
Semily & 0 & 2 & 0 \\
Náchod & 0 & 1 & 1 \\
Rychnov nad Kněžnou & 0 & 2 & 1 \\
Brno - město & 1 & 6 & 15 \\
Praha 4 & 1 & 1 & 0 \\
Praha 5 & 0 & 3 & 1 \\
Pardubice & 1 & 0 & 0 \\
Liberec & 1 & 1 & 1 \\
Hradec Králové & 1 & 1 & 3 \\
Nymburk & 0 & 2 & 1 \\
\hline
\end{tabular}

Four questions in the questionnaire were investigating the structure of the education and its staffing and funding. Staffing is influenced by former development as well. The swimming education is taught by swimming teachers in 347 kindergartens (59 \%), lifeguards and pool personnel in 215 ones (36\%). Kindergarten teachers teach the whole swimming education only in 28 kindergartens (5\%), while half of these kindergartens is represented by kindergartens in Brno-City, where there is also the highest number of school pools. The swimming teachers prepare for their work in special courses and they have to have license of swimming teacher. The kindergarten teachers have right education too. By contrast lifeguards and other pool personnel have knowledge about pool operating but not about teaching children. The lifeguards as teacher are used where are not swimming schools because they are cheaper then swimming teacher.

The education in 553 (94\%) kindergartens costs up to 1500 CZK (60 €), out of which 114 kindergartens (19\%) pay only up to 500 CZK. Higher price is paid especially in metropolitan counties; 19 in Brno-City, next 19 in Prague 4 Liberec, Náchod and Olomouc. A structure of costs is similar too and it is presented in Table 3. A hire of pool, earnings of teachers and transport to pool creates the price of the swimming education.

Table 3. Kind of costs (source: authors)

\begin{tabular}{ccccc}
\hline county & pool & teachers & transport & other \\
\hline Ústí nad Orlicí & 78 & 78 & 62 & 0 \\
Žd’ár nad Sázavou & 35 & 52 & 48 & 0 \\
Olomouc & 28 & 28 & 25 & 2 \\
Svitavy & 59 & 58 & 38 & 2 \\
Chrudim & 40 & 40 & 31 & 0 \\
Česká Lípa & 10 & 14 & 12 & 0 \\
Jablonec nad Nisou & 26 & 27 & 25 & 0 \\
Semily & 11 & 16 & 14 & 0 \\
Náchod & 32 & 38 & 29 & 0 \\
Rychnov nad & 13 & 12 & 12 & 0 \\
Kněžnou & 11 & 59 & 43 & 0 \\
Brno - město & 16 & 17 & 2 & 0 \\
Praha 5 & & & &
\end{tabular}




\begin{tabular}{ccccc} 
Praha 4 & 18 & 18 & 7 & 1 \\
Pardubice & 24 & 22 & 18 & 0 \\
Liberec & 15 & 15 & 4 & 0 \\
Hradec Králové & 31 & 30 & 10 & 0 \\
Nymburk & 35 & 34 & 20 & 0 \\
\hline summary & 482 & 558 & 400 & 5 \\
\hline
\end{tabular}

To be able to evaluate some of the above stated claims more precisely, we also asked for reasons why kindergartens do not attend the swimming education. Despite of the fact not all kindergartens specified these reasons we can make some conclusions. These reasons are shown in Figure 6 Almost $20 \%$ of kindergartens states financial demands as the main reason. However, we must emphasize that the prevailing price (up to $1500 \mathrm{CZK}$ ) is low even in Czech conditions and that it is hardly possible to provide less expensive swimming education. The price in $95 \%$ covers the expenses on instructors, in $82 \%$ expenses on the pool and its running, in $68 \%$ expenses on transport to the pool. This is the percentage of the total number of kindergartens; the structure of overall costs is considerably unbalanced among individual counties. The main costs of the education are paid by the family (almost $100 \%$ ) but in $5 \%$ of cases the municipality is willing to contribute and in $4 \%$ of cases the school contributes directly from its own budget. Unfortunately, to procure a sponsor for the education is almost impossible (1\%).

Higher transport costs, not directly related to the education, may be explained even by longer driving distance to the pools in agricultural counties. Complicated transport (not expensive) to the pool is the second most common reason for kindergartens not to attend the swimming education. Almost in half of the cases the transport is arranged by kindergartens themselves (45\%), in $18 \%$ the transport is provided by swimming schools within their offers and in $17 \%$ the kindergartens use public transport. Only $19 \%$ of kindergartens walk to the pool.

Other most common reasons are operational reasons on the side of the kindergarten and indifference of parents. Marginal reasons are inappropriate pool conditions or the methodology of education used.

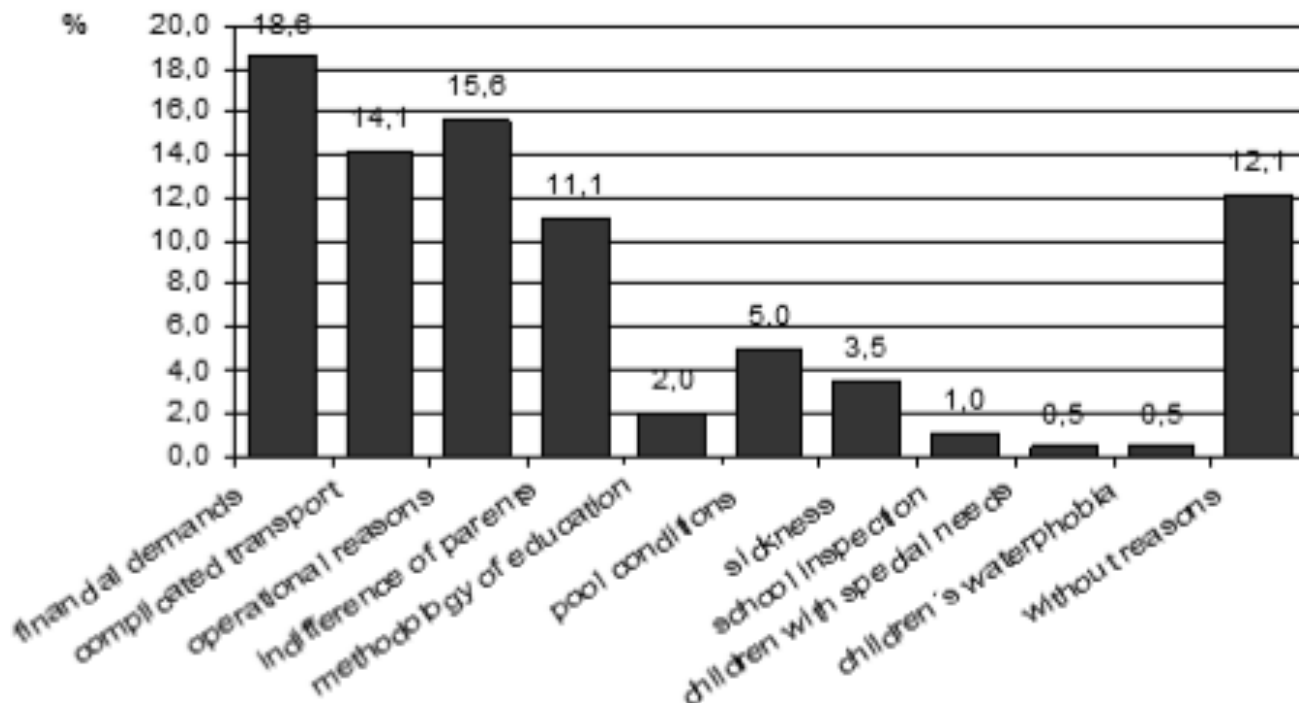

Figure 6. Reasons for non attending swimming education (source: authors) 


\section{CONCLUSIONS}

It has been found out that there is interest in the organized swimming education for kindergartens. The education can be arranged for all kindergartens, in case the swimming schools are able to provide optimal conditions and solving problems concerning attendance of the education. Longer driving distance of the kindergarten from the pool can be compensated by transport of children to the pool and ideal lesson plan (10 times 1 hour per week). Among the ideal conditions belong the price up to $1500 \mathrm{CZK}$ and qualified teachers of swimming.

An unexpected result of the research is the fact that lower interest in swimming education is in metropolitan counties, where there are very good conditions and easily accessible pools. The kindergarten teachers in these counties explained that there is a varied offer of activities and that they tend to choose the less demanding activities in terms of organization. We add that there is a high price of swimming education in Brno - City and Prague 4, which plays its role in decisions and we believe that it is possible to lower the price.

According to our findings, there was a unique system of school swimming education in the Czechoslovakia, which covered the entire children population for several generations. The present situation is not critical from this point of view as well. Elementary schools still have the swimming education in their educational programmes. Moreover, the education has expanded to kindergartens, where the education concerns three quarters of kindergartens. What consequences will this trend have?

The shift of swimming education can be considered a positive change. Preschool children adapt to the water environment and some of them also acquire the basics of swimming. Yet, in case no other education follows at the elementary school, the trend may become not even negative but also dangerous. Children at the age of 5-7 years learn the basics of swimming, which are not further developed. Thus, the acquired abilities fade away. Not only children but also their parents are often unable to estimate their swimming abilities and underrate the danger that is in the water and in the pool. In case we pay a lot of attention to swimming in the preschool age, we must consider further development even in the future. This is the responsibility of both parents and consequently the system that provides the organized education (more in Roztočil \& Stloukalová, 2007).

All the more so as one can notice another trend in the relation of the public to swimming during the recent 10 years - construction of pools with water slides. More than tens of pools have been rebuilt into recreation pools with slides, whirlpool tubs and water jets at the expense of sports swimming pools. What impact this trend will have on further development of swimming education is a question because swimming is slowly changing into bathing.

\section{REFERENCES}

1. Czech Statistical Office (2014). Český statistický úrad. Retrieved from http://www.czso.cz/

2. Gavora, P. (1996). Výzkumné metody v pedagogice. Brno: Paido.

3. Hoch, M. (1983). Plavání. Teorie a didaktika. Praha: SPN.

4. Pírková, L. (2008). Plavání jako součást výuky na základní škole. Hradec Králové. (Unpublished Tesis). Univerzita Hradec Králové. Faculty of Education.

5. Framework Educational Programme for Pre-primary Schools (2004). Praha: Výzkumný ústav pedagogický. 
6. Roztočil, T., \& Stloukalová, B. (2007). Problematika plavecké gramotnosti u české populace. In Optimální působení tělesné zátěže a výživy. Hradec Králové: Faculty of Education, University Hradec Králové.

7. Stloukalová, B. (2011). Teaching Physical Education at Pre-primary Schools. Hradec Králové: Faculty of Education. Retrieved from http://kurzy.uhk.cz/course/view.php?id=40

8. Stloukalová, B., \& Roztočil, T. (2013). Management of Swimming Education in Kindergarten in Czech Republic. In Early childhood education (ECED 2013), proceedings of the 1st international conference (pp. 120-124). Athens (GR): World scientific and engineering academy and society.

9. Thomas, J.R., \& Nelson, J.K. (1996). Research methods in physical activity. Champaign: Human Kinetics. 